\title{
Inadequate fluid intake can increase the risk of constipation among pregnant women
}

\author{
Dina Fitriana, Budi Prasetyo, Bangun Trapsila Purwaka
}

Department of Obstetrics and Gynecology, Faculty of Medicine Airlangga University, Dr. Soetomo Hospital, Surabaya

\section{ABSTRAK}

Tujuan: mengetahui hubungan antara pola nutrisi serat dan asupan cairan dengan konstipasi pada ibu hamil di Puskesmas Jagir Surabaya.

Bahan dan Metode: Penelitian analitik asosiatif cross-sectional dilakukan di Puskesmas Jagir Surabaya dengan sampel wanita hamil sehat umur 20-35 tahun $(n=99)$. Responden mencatat jumlah asupan cairan, frekuensi defekasi dan tipe faeces setiap hari selama 7 hari, serta dilakukan food recall selama 24 jam. Dinilai cukup asupan cairan pada TM I sebanyak $2180 \mathrm{cc} / \mathrm{hari}$ dan $2300 \mathrm{cc} / \mathrm{hari}$ untuk TM II dan TM III. Sedangkan dinilai cukup asupan serat pada wanita hamil adalah 25-30 gram/hari. Didiagnosis konstipasi apabila dari pencatatan didapatkan frekuensi defekasi <2x/minggu, atau pada Bristol Stool Form Scale tergolongkan dalam tipe 1, tipe 2, atau tipe 3 .

Hasil: Angka kecukupan asupan cairan ibu hamil sebesar 40,4\%, angka kecukupan asupan serat ibu hamil sebesar 4,1\%, dan angka kejadian konstipasi pada ibu hamil $29,5 \%$. Terdapat hubungan yang bermakna antara asupan cairan dengan kejadian konstipasi p: 0,000 ; RR:1,85. Tidak didapatkan hubungan yang bermakna antara asupan serat dengan kejadian konstipasi dengan p:0,317 $(\mathrm{p}<0,05)$. Tidak didapatkan hubungan yang bermakna antara paritas, usia kehamilan dan tingkat pendidikan dengan kejadian konstipasi dengan $(\mathrm{p}<0,05)$.

Simpulan: Asupan cairan yang kurang dapat meningkatkan risiko terjadinya konstipasi 1,85 kali pada ibu hamil dan asupan cairan yang cukup dapat mencegah konstipasi pada ibu hamil.

(MOG 2017;25:48-53)

\begin{abstract}
Objectives: To analyze the association between the fiber and fluid consumption with constipation in pregnancy.

Materials and Methods: An analytic cross-sectional study conducted at Jagir Public Health Center Surabaya, with the samples of healthy pregnant women aged between 20-35 years old $(n=99)$. Respondents were asked to record the amount of daily fluid intake, defecation frequency, and type of faeces, everyday for 7 days, also made a food recall during 24 hours. The recommendation of adequate fluid intake in first trimester was 2180 $\mathrm{ml} /$ day and $2300 \mathrm{ml} /$ day for second and third trimester. The value of adequate fiber consumption was $25-30 \mathrm{~g} / \mathrm{day}$. Constipation diagnosed by the frequency of defecation $<2 x /$ week, or based on Bristol Stool Form Scale included as type 1, type 2, or type 3.

Results: Pregnant women whose adequate fluid intake was $40,4 \%$ and those with adequate fiber intake was $4.1 \%$. The percentage of constipation among them was $29.5 \%$. There was significant association between fluid intake and constipation (p: 0,000; RR:1,85). There was no significant association between fiber intake and constipation p:0,317 $(\mathrm{p}<0.05)$. There was also no significant association between parity, gestational age, and level of education with constipation $(\mathrm{p}<0.05)$.

Conclusion: Inadequate maternal fluid intake can increase the risk of constipation by 1.85 folds, and the adequate fluid intake may prevent constipation during pregnancy. (MOG 2017;25: 4853)
\end{abstract}

Keywords: fluid intake; fiber intake; constipation

Kata kunci: asupan cairan; asupan serat; konstipasi

Correspondence: Dina Fitriana, Department of Obstetrics and Gynecology, Faculty of Medicine Airlangga University, Dr. Soetomo Hospital, Surabaya, Indonesia. phone: +62315501474, e-mail: dinachantique_82@yahoo.com

\section{INTRODUCTION}

Constipation is one of the complaints often felt by pregnant women. Many factors may cause constipation. During pregnancy, body adaptation is taking place, marked by drastic hormonal changes, one of which is constipation that emerged starting at the beginning of pregnancy. Pregnancy is a physiological event, during which the body will experience many changes, whether physical mood, or hormonal changes that can cause various complaints, including constipation. Incidence of constipation in pregnant women in Indonesia reaches $15-20 \%$. $^{1}$ Another factor that can cause constipation in pregnancy is the body that tends to retain fluids that result in harder and drier digestive tract. ${ }^{2}$ Constipation is defined as the slow movement of faeces through the colon, associated with the large number of dry and hard faeces collected in the descendent colon due to excessive fluid absorption. ${ }^{3}$ Constipation is a symptom often complained of by pregnant women, which can cause discomfort. ${ }^{1,4}$

Consumption of iron-containing pills tends to have a constipation effect in some pregnant women. In addition, lack of physical activity during pregnancy also contributes to the cause of constipation. Constipation is associated with at least 6 different conditions in the body, eg enlarging uterus pressing the rectum and colon to interfere with excretion, increased levels of progesterone relaxes gastrointestinal muscles and decreases motility, inadequate fluid intake, insufficient fiber diet, 
iron supplements, bad defecation habit, rare exercise and often miss a meal, especially breakfast. ${ }^{5,6}$

During pregnancy, water demand increases as it is used to support fetal circulation, increased amniotic fluid production and blood volume. Water demand is strongly influenced by many factors such as pregnant women's activity, ambient temperature, shelter and so on. The average energy requirement during pregnancy increases 300 calories/day. Humans need $1-1.5 \mathrm{ml}$ of water per calorie consumed. Therefore, pregnant women require at least $300 \mathrm{ml}$ of additional water intake (8-10 glasses of water per day). ${ }^{7}$ Other causes are pressure on the intestine by the presence of enlarged uterus, as well as hormonal influences in pregnancy which result in relaxation of the muscles of the body, including the muscles of the intestine. ${ }^{8}$

A diet lacking of fiber can also lead to constipation, ${ }^{4}$ coupled with stress and anxiety during pregnancy. To overcome this problem, pregnant women are advised to avoid three large meals a day and eat low but frequent amounts of food, so as to optimize intestinal work. ${ }^{5}$ In addition, drinking water in large quantities can neutralize toxins in the body. Mild physical activity can benefit the digestive system. Ginger consumption in early pregnancy, which in general is to reduce symptoms of nausea, vomiting, can also be used as an effort to prevent constipation in pregnancy. Foods that contain lots of natural fiber, such as vegetables and fruits, are very important for consumption to help reduce complaints of constipation during pregnancy.

\section{MATERIALS AND METHODS}

This study was a community-based cross-sectional associative analytic study conducted at Jagir Public Health Center, Surabaya, between March - April 2014. The population in this study was pregnant women who performed antenatal examination at Jagir Public Health Center during that period. Samples taken were pregnant women of trimester I, II, III. Sampling was done by consecutive sampling method, based on inclusion and exclusion criteria. The inclusion criteria in this study were pregnant women 20-35 years old, of the first trimester (gestational age 0-14 weeks), second trimester (gestational age 15-28 weeks), and third trimester (gestational age 29-40 weeks), under healthy conditions (based on history taking and physical examination), residing in Jagir Puskesmas area, able to communicate both oral and written, willing to participate in this study. The exclusion criteria were having diabetes mellitus, hypertension, heart disease, kidney disease, diarrhea, fever and infectious diseases, have a history or are taking laxatives. Criteria for drop out in this study were unable to meet the daily diary of fluid intake for 7 days and food intake (fiber) within 24 hours. After screening and physical examination, each study subject who was willing to participate in the study was given a questionnaire at the beginning of the meeting. Each subjects were given with two types of forms to record the amount of fluid intake, frequency of defecation and type of feces, and the results were taken every day that lasted for 7 days.

One person dropped out because they were unable to meet the daily intake of fluid and fiber, so that the sample that met the criteria amounted to 99 individuals $(n=99)$. Subjects with constipation were asked to check themselves to Jagir Public Health Center and consulted to a local obstetrician and gynecologist for further education and treatment. Instruments used in this study were Tanita BC 571 weight scales, questionnaires, daily fluid intake diaries for 7 days, daily frequency of defecation, type of feces for 7 days, and food intake recall for 24 hours.

Respondents were asked to record the amount of fluid intake, frequency of defecation and type of faeces every day for 7 days, and food recall for 24 hours. Liquid intake in TM I was considered sufficient if it was as much as $2180 \mathrm{cc} /$ day and for TM II and TM III as much as $2300 \mathrm{cc} /$ day. Fiber intake in pregnant women was considered sufficient when it was 25-30 grams/day. Constipation was diagnosed if the recording was found to have a defecation frequency of $<2 x /$ week, or in Bristol Stool Form Scale belonging to type1, type 2, or type 3. Statistical analysis of significance level used Chi-square with significance level $\mathrm{p}<0.05$.

\section{RESULTS AND DISCUSSIONS}

Of the 99 samples included in the inclusion criteria, the age range was 20 to 35 years with an average age of 28.76 years. The highest level of education was secondary education, ie high school graduation as much as $52.5 \%$ followed by junior high school as much as $20.2 \%$. Of the total sample, 55 individuals or $55.17 \%$ worked as housewives, 25 of them worked as employees, nurses as many as 4 individuals, and assistant pharmacist 2 individuals. Only 1 person worked as factory worker and 2 as civil servant. The sample was divided into 3 groups: 35 first trimester pregnant women, 33 trimester II pregnant women and 31 trimester III pregnant women with almost the same proportion. Parity was classified into primigravida $35.5 \%$ and multigravida as much as $64.5 \%$.

The incidence of constipation in pregnant women was $29.5 \%$. Of 99 samples, pregnant women who had con- 
stipation were 29 (29.5\%), while the rest had no complaints of constipation. This constipation incident was based on the type of faeces according to The Bristol Stool Form Scale. Based on The Bristol Stool Form Scale, of the 99 samples the predominant one was type 4 in as many as 36 individuals (19\%), whereas in types 4 to 7 showed no constipated faecal type, while type 1 to 3 was a type of constipated faeces. There were 29 constipation complaints, mostly type 3 (20 individuals, $14 \%$ ), while the others were of the type 1 and type 2 .

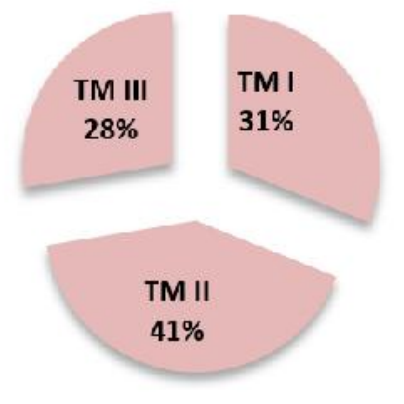

Figure 1. Distribution of the number of constipation incidence by gestational age

Overall, according to gestational age, $29.5 \%$ had constipation and $70.5 \%$ had no constipation. Of each age group of pregnancy, the incidence rate of constipation on TM I was 9 (31\%), TM II 12 (41\%), and TM III $8(28 \%)$. The highest percentage of constipation was in TM II gestational age and the lowest was in TM III.

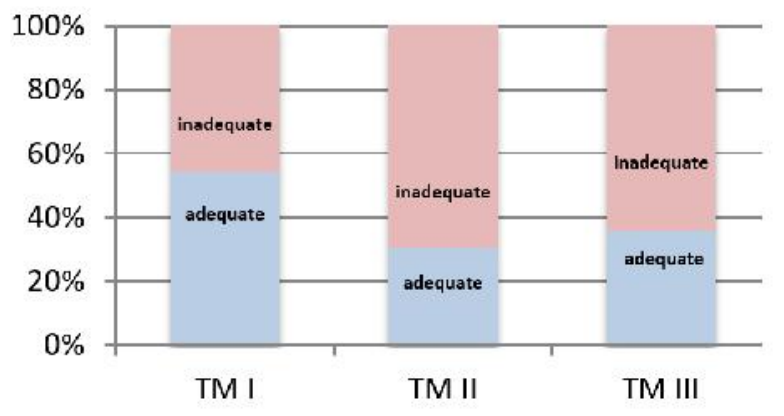

Figure 2. Distribution of fluid intake adequacy based on gestational age

Overall, the average daily fluid intake by gestational age showed $40.4 \%$ adequate and $59.6 \%$ inadequate. The percentage of fluid intake adequacy was the highest in TM I gestational age and the lowest was in TM II. Overall, assessment of fiber intake per day by gestational age showed $4.1 \%$ adequate and $95.9 \%$ inadequate. The percentage adequacy of fiber intake was the highest in TM I gestational age and the lowest age was in TM II and TM III.

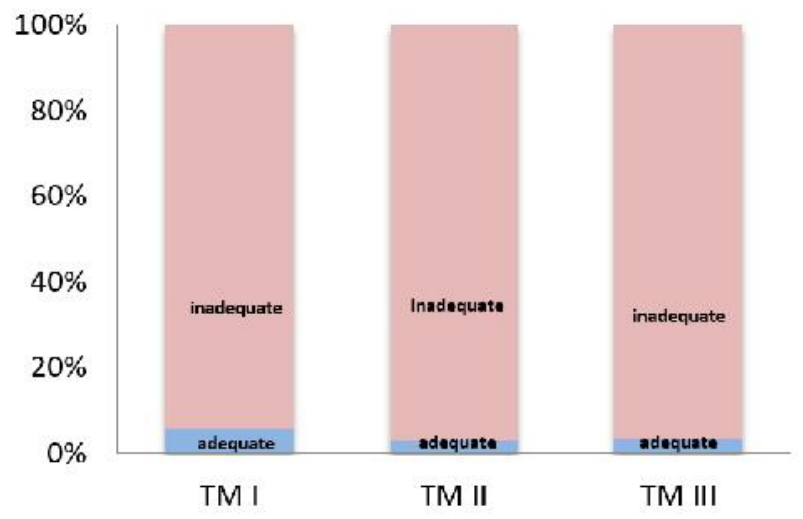

Figure 3. Distribution of fiber intake adequacy based on gestational age

Table 3. Incidence of constipation based on influencing factors

\begin{tabular}{|c|c|c|c|c|c|}
\hline & & $(\mathrm{N})$ & Constipation(+) & Constipation(-) & $p$ \\
\hline \multirow[t]{2}{*}{ Parity } & Primigravida & 35 & $13(37.1 \%)$ & $22(63.9 \%)$ & 0.299 \\
\hline & Multigravida & 64 & $15(23.4 \%)$ & $49(76.6 \%)$ & \\
\hline \multirow[t]{3}{*}{ Pregnancy Age } & Trimester I & 35 & $9(25.7 \%)$ & $26(74.3 \%)$ & 0.550 \\
\hline & Trimester II & 33 & $12(36.3 \%)$ & $21(63.7 \%)$ & \\
\hline & Trimester III & 31 & $8(25.8 \%)$ & $23(74.2 \%)$ & \\
\hline \multirow[t]{3}{*}{ Education level } & Low & 5 & $0(0 \%)$ & $5(100 \%)$ & 0.231 \\
\hline & Moderate & 72 & $24(33.3 \%)$ & $48(66.7 \%)$ & \\
\hline & High & 22 & $4(18.2 \%)$ & $18(81.8 \%)$ & \\
\hline \multirow[t]{2}{*}{ Fluid Intake } & Adequate & 40 & $0(0 \%)$ & $40(100 \%)$ & $0.000^{*}$ \\
\hline & Inadequate & 59 & $29(49.2 \%)$ & $30(50.8 \%)$ & $\begin{array}{c}\text { (RR:1. } \\
\text { (RR) }\end{array}$ \\
\hline \multirow[t]{2}{*}{ Fiber Intake } & Adequate & 4 & $1(25 \%)$ & $3(75 \%)$ & 0.317 \\
\hline & Inadequate & 95 & $28(29.5 \%)$ & $67(70.5 \%)$ & \\
\hline
\end{tabular}

*Significant if $\mathrm{p}<0.05 . \mathrm{RR}=$ Relative Risk

Comparative test results using Chi-square between fluid intake and constipation incidence showed significant result of p: $0.000(p<0.05)$, while the relative risk of constipation to inadequate fluid intake was less than 1.85 times compared to adequate fluid intake (RR: 1.85). Conversely, no significant difference was found between parity, gestational age, education level and fiber intake with constipation incidence in pregnant women ( $>0.05)$.

The youngest age in this study was 20 years old and the oldest 35 years old with an average age of 28.76 years. We took age range group of 20 to 35 years because this age group belonged to group with a low-risk complications in pregnancy. The majority of subjects in this study had a secondary education level, the junior and senior high school. This was in accordance with the site of the study where the primary service facility was the one usually visited by those from lower middle socioeconomic class.

In this study, the incidence of constipation in pregnant women was 29.5\%. In the United States in 2006 over 4 million people had frequent complaints of constipation, 
resulting in a prevalence of about $2 \%$. Pregnant women also often complain of constipation. Approximately 2.5 million patients visit the doctor every year. ${ }^{9}$ According to Probosuseno (2007), in Indonesia consti-pation cases suffered by $4-30 \%$ of pregnant women.

\section{Association between fluid intake adequacy and constipation incidence}

The average assessment of fluid intake in this study refers to Indonesian Society of Obstetrics and Gynecologists' recommendation that fluid intake requirement in TM I is $2180 \mathrm{ml} /$ day while in TM II and III is 2300 $\mathrm{ml} /$ day. In this study, from 99 samples, $40.4 \%$ had adequate fluid intake and $59.6 \%$ inadequate. This shows the adequacy of fluid in pregnant women was not met so that nutritional education needs to be given, among others, about the importance of adequacy of fluid intake. It should be emphasized, however, that fluid intake should vary because excessive consumption of water may lead to water intoxication and hyponatremia. ${ }^{10}$

This study found a significant association between the adequacy of fluid intake and constipation in pregnant women $(p=0,000 ; R R: 1.85)$. Similar results were also obtained in a study conducted by Nur Aisyah (2014), that there was a significant association between fluid intake and incidence of constipation in pregnant women.

The gastrointestinal tract is a series of mucous membrane channels. The function of this organ is to absorb fluids and nutrients, prepare food for absorption and use by body cells, and is a temporary site for feces. The volume of fluid absorbed by numerous gastrointestinal tracts. Liquid balance is a major function of the gastrointestinal system. In the process of digestion of fluids and foods, the gastrointestinal tract also gets a lot of secretions from organs such as the gallbladder and pancreas. Serious illness can impair absorption and normal secretion of the gastrointestinal tract due to fluid imbalances. ${ }^{11}$

Water can be absorbed by the colon within 24 hours. An average of $55 \mathrm{mEq}$ of sodium and $23 \mathrm{mEq}$ of chloride was absorbed daily. The amount of water absorbed from the chyme depends on the speed of colon movement. Chyme is usually soft, mass-shaped. If the peristaltic contractions is rapid (abnormal), there is a lack of time to absorb water and feces become dilute. If the peristaltic contraction is slow, a lot of water is absorbed and hard stool forms, causing constipation. The colon protects itself by secreting a number of mucous. Mucous is usually clean to opaque with a stringy consistency. Mucous lubricates the colon, preventing trauma to the inner walls. The lubricant is something of importance near the distal of the colon where its parts become dry and hard. The secretion function of the colon helps the electrolyte balance. Bicarbonate is secreted for chloride exchange. About $4-9 \mathrm{mEq}$ of sodium is released daily by the large intestine. Changes in the function of the colon may cause electrolyte imbalances. ${ }^{12}$ In this study it was found that lack of fluid intake in pregnant mothers increased the risk of constipation 1.85 times higher compared with adequate fluid intake (RR: 1.85).

\section{Association between fiber intake adequacy and constipation}

We found no significant association between the adequacy of fiber intake and constipation in pregnant women ( $p>0.05$ ). A study by Dharna (2010) found a significant association between low-fiber diet and constipation in pregnant women. But Aisyah's study (2014) found no significant association between fiber intake and constipation. This is associated with the type of food ingredients consumed by individuals, which is thought to be one of the influencing factors.

Constipation generally occurs due to a diet that is lacking in fiber, lack of drinking, lack of physical activity, and because of changes in rhythm or frequency of defecation. Pregnancy, and possibly medication, can cause constipation. ${ }^{13}$ Soft and low fiber foods are reduced in the feces to produce insufficient residual products to stimulate reflexes in the defecation process. Low fiber diets like rice, eggs and fresh meat move more slowly in gastrointestinal tract. Increased fluid intake with such foods increases the movement of these foods. ${ }^{14}$

Difficult bowel movement is often experienced by pregnant women. Hormonal changes due to pregnancy or lifestyle can lead to this disorder. Initially, constipation only causes discomfort during defecation and stomach becomes sick or bloated. However, if this lasts longer, it will disturb the body's metabolism and cause other body disorders. ${ }^{15}$

\section{Association between gestational age and constipation}

The study obtained a $25.7 \%$ constipation rate in TMI, $36.3 \%$ in TM II and $25.8 \%$ in TM III. However, the comparative test of the association between gestational age and constipation was not significant ( $p>0.05$ ). According to Bradley (2007), of 103 pregnant women, $24 \%$ had constipation in the first trimester, $26 \%$ in the second trimester, and $26 \%$ in the third trimester. Similar results were also obtained in Nur Aisyah (2014) study, that there was no significant association between gestational age and constipation in pregnant women. In the first trimester constipation is not often experienced by 
pregnant women, but only in the second and third trimester gestational age. This is thought to be due to a decrease in peristaltics caused by smooth muscle relaxation in the large intestine when an increase in the amount of progesterone occurs. ${ }^{16}$

\section{Association between parity and constipation}

Parity is the number of pregnancies that produce a fetus capable of living outside the uterus with a 28 -week gestational age. The division of parity is as follows: First, primipara, a woman who first gave birth where the fetus reaches 28 weeks gestation or more. Second, multipara, a woman who has been pregnant with a gestational age of at least 28 weeks and has given birth 2 or more times. Third, grande multipara, a woman who has been pregnant with a gestational age of at least 28 weeks and has given birth more than 5 times. ${ }^{17}$

Mothers who are too often pregnant can deplete the nutrients in the body. ${ }^{13}$ Shorter birth spans do not allow sufficient time for the mother to restore the level of nutritional reserves necessary for the development of the mother and fetus body. In addition, it will be an additional burden on the mother's own body because there is not enough time between pregnancies that causes the mother is unable to replace the stock of nutrients in the body that has been used by himself and his son. This will make the mother and her child vulnerable to malnutrition. ${ }^{18}$ There was no significant association between parity and constipation in pregnant women $(\mathrm{p}>0.05)$.

\section{Association between education level and constipation}

Education level is often related to socioeconomic level and health maintenance habits. Education level also affects the knowledge of healthy ways of living. This study did not find association between education level and constipation incidence in pregnant women $(\mathrm{p}>0.05)$. However, a study by Faizatul (2010) found a positive association between education level and incidence of constipation in pregnant women.

An educated society with sufficient knowledge of nutritional value is more concerned with physiological needs than psychological satisfaction needs. But generally there will be a compromise between the psychic needs and physiological needs of the body, so there will be a composition of dishes that meet the psychological satisfaction as well as physiological needs of the body. Mothers who are less educated or uneducated are generally unable or difficult to under-stand the negative impacts of malnutrition on themselves, on their children and their families. This affects the selection of foodstuffs that are consumed daily in terms of both quality and quantity. ${ }^{19}$ In some studies low socioeconomic status has been shown to be associated with increased risk of constipation as low socio-economic status is associated with nutritional intake and immunity, particularly in pregnant women. ${ }^{20}$ Pregnant women with low socioeconomic status tend to have less nutrition. This will affect the ability to consume food and nutrients, because consuming fiber-rich foods is very helpful for constipation patients. ${ }^{21}$ Thus, pregnant women with low socioeconomic levels tend to suffer from malnutrition, allowing for the incidence of constipation in pregnancy. However, in this study these factors were not included in analysis.

\section{CONCLUSIONS}

All pregnant women with sufficient fluid intake did not experience constipation. This suggests that $40.4 \%$ of pregnant women around the Jagir Public Health Center area have a reliable lifestyle in terms of fluid intake. In pregnant women, lack of fluid intake may increase the risk of constipation 1.85 times compared to adequate fluid intake.

\section{REFERENCES}

1. Philip, $\mathrm{O}$ and Crisp S. Constipation during pregnancy. J Gen intern Med. 2000;69:200-2.

2. Jewell DJ and Young G. Interventions for treating constipation in pregnancy. In: Primary sources Cochrane pregnancy and child birth grow brails register. The Cochrane Library and Medline. Chichester, UK: John Wiley and Sons, Ltd; 2007.

3. Guyton AC and Hall JE. Constipation. In: Medical Physiology: Physiology of gastrointestinal disorder. 11th eds. Elseveir Publishers; 2006. p. 81925.

4. Anderson JW, Baird P, Davis RH. Health benefits of dietary fiber. Nutr Rev. 2009;67(2): 188-205.

5. Mayo clinic guide to a healthy pregnancy Harms 2008;Part 3

6. Kartono D, Jahari AB, Sulaeman A, et al. Angka Kecukupan Gizi (AKG) 2012 untuk orang Indonesia. In: Widyakarya Nasional Pangan dan Gizi X. Jakarta; 2012.

7. Montgomery KS. Nutrition column. An update on water needs during pregnancy and beyond. J Perinat Educ. 2002;11:40-2.

8. Bradley CS, Kennedy CM, Turcea AM, et al. Constipation prevalence and risk factors in pregnancy. J Gen Intern Med. 2002;64:195-8.

9. Tunjung R. Malnutrisi. [Internet]. [updated 2009 May 19; cited 2009 November 1] ; Available from:URL:http://dokterblog.wordpress.com/2009/ 
05/19/malnutrisi/Department of Health and Ageing. 2009. Healthy eating at various life stagespregnant women.

10. Beall MH, van den Wijngaard JP, van Gemert MJ, Ross MG. Amniotic fluid water dynamics. Placenta. 2007;28:816-23

11. Alberts DS, Martinez ME, Roe DJ, (2000). Lack of effect of a high-fiber cereal supplement on the recurrence of colorectal adenomas. $\mathrm{N}$ Engl J Med. 2000;342: 1156-62.

12. Mauro B, Maurizio L, Andrea I, Giosue. Effect of a balanced mixture of dietary fibers on gastric emptying, intestinal transit and body weight. Ann Nutri Metab. 2008. 52:221-6.

13. Hariadi R. Nutrisi janin dan transfer plasenta. In: Winkjosastro $\mathrm{G}$, editor. Ilmu kedokteran fetomaternal. Surabaya: Himpunan kedokteran fetomaternal; 2004. p. 135, 154

14. Huliana. Panduan menjalani kehamilan sehat. In: Gizi dalam kesehatan reproduksi. Jakarta: Penerbit Buku Kedokteran. EGC.

15. Armstrong LE. Urinary indices during dehydration, exercise, and rehydration. Int $\mathrm{J}$ Sport Nutr. 1998;8(4):345-55
16. Badan Penelitian dan Pengembangan Kesehatan Kementerian Kesehatan RI. Riset Kesehatan Dasar (Riskesdas). Jakarta: 2010

17. Bentley GR. Hydration as a limiting factor in lactation. American Journal of Human Biology. 1998;10:151-61.

18. Cetin I, Nobile de Santis MS, et al. Maternal and fetal amino acid concentrations in normal pregnancies and in pregnancies with gestational diabetes mellitus. Am J Obstet Gynecol. 2005; 192:610.

19. Food and Nutrition Board, Institute of Medicine of the National Academies. Dietary reference intake of energy, carbohydrate, fiber, fat, fatty acids, cholesterol, protein, and amino acid (Macronutrients). National Academies Press; 2005. p 380-2.

20. Institute of Medicine. Subcommittee on Nutritional Status and Weight Gain During Pregnancy. Nutrition during pregnancy. Washington DC: National Academy Press; 2009.

21. Derbyshire E, Davies J, Costarelli V. Diets, Physical inactivity and the prevalence of constipa-tion throughout and after pregnancy. Matern child Nutri. 2006;2:127-34. 